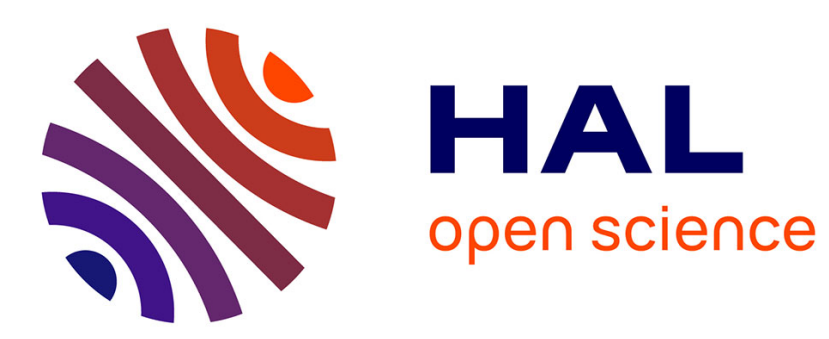

\title{
Neoformation of DLH During Impregnation of $\alpha$-Alumin
} J.-B. d'Espinose de La Caillerie, O. Clause

\section{To cite this version:}

J.-B. d'Espinose de La Caillerie, O. Clause. Neoformation of DLH During Impregnation of $\alpha$-Alumin. Journal de Physique IV Proceedings, 1997, 7 (C2), pp.C2-957-C2-958. 10.1051/.jp4:19972100 . jpa00255157

\section{HAL Id: jpa-00255157 https://hal.science/jpa-00255157}

Submitted on 1 Jan 1997

HAL is a multi-disciplinary open access archive for the deposit and dissemination of scientific research documents, whether they are published or not. The documents may come from teaching and research institutions in France or abroad, or from public or private research centers.
L'archive ouverte pluridisciplinaire HAL, est destinée au dépôt et à la diffusion de documents scientifiques de niveau recherche, publiés ou non, émanant des établissements d'enseignement et de recherche français ou étrangers, des laboratoires publics ou privés. 


\title{
Neoformation of DLH During Impregnation of $\gamma$-Alumina
}

\author{
J.-B. d'Espinose de la Caillerie and O. Clause
}

Ecole Supérieure de Physique et de Chimie Industrielles, Laboratoire de Physique Quantique, URA 1428 du CNRS, 10 rue Vauquelin, 75231 Paris cedex 05, France

* Institut Français du Pétrole, Division Cinétique et Catalyse, BP. 311, 92506 Rueil-Malmaison cedex, France

\begin{abstract}
The adsorption of $\mathrm{Co}(\mathrm{II})$ or $\mathrm{Ni}(\mathrm{II})$ ammine complexes from aqueous solutions onto $\gamma$-alumina at neutral $\mathrm{pH}$ and ambient temperature was investigated. The formation of coprecipitates including $\mathrm{Al}$ (III) ions extracted from the support was demonstrated by EXAFS for contact times and $\mathrm{Ni}$ or Co loadings higher than $0.5 \mathrm{~h}$ and about $2.0 \mathrm{wt} \%$, respectively. The EXAFS technique makes it possible to distinguish the Ni or Co hydroxides and basic nitrates from coprecipitates with a double layer hydroxide (DLH) structure. Not only is EXAFS shown to be sensitive to the presence of aluminum in the coprecipitates, but in most cases, the $\mathrm{M}(\mathrm{I}) / \mathrm{Al}(\mathrm{III})$ ratio $(\mathrm{M}=\mathrm{Ni}$ or $\mathrm{Co}$ ) in the supported coprecipitates can be estimated. Thus, alumina should not be considered systematically as inert even at $\mathrm{pH}$ values close to its isoelectric point. It is suggested that a dissolution-precipitation mechanism is involved and that the rate of alumina dissolution is promoted by adsorbed Ni(II) or $\mathrm{Co}(\mathrm{II})$ ions. Site-binding models have a considerable value for the early stages of impregnation, whereas a geochemical approach involving surface rehydration and coprecipitation have probably a greater validity for the later stages.
\end{abstract}

\section{INTRODUCTION}

The understanding of the nature of the interaction between solvated ions and solid oxides surfaces is fundamental to diverse areas of chemistry such as heterogeneous catalyst preparation, geochemistry, and environmental chemistry. A solid catalyst usually consists of a chemically active species dispersed by impregnation or adsorption of a solvated precursor on an oxide solid surface chosen for its textural and mechanical properties. The system to be described when studying the first stage of catalyst preparation therefore consists of an aqueous solution / solid oxide interface. While geochemists studying weathering and the interaction of minerals with hydrothermal fluids have focused on the solubility of minerals and surface leaching, phenomena invoked for the fixation of solvated metal cations during the preparation of supported catalysts have relied exclusively on electrostatic [1] and ligand exchange models [2] developed within the framework of colloid chemistry. In the field of catalyst preparation, the formation of surface phases involving both the dispersed species and elements of the support has mainly been considered to occur during the later stages of preparation such as drying or activation at high temperature [3]. However, we have recently submitted evidence for the formation of lamellar surface species during impregnation of divalent cations at room temperature and near-neutral $\mathrm{pH}$ on silica [4] and alumina [5]. Here we focused on the alumina/water interface during impregnation with $\mathrm{Ni}$ (II) or $\mathrm{Co}$ (II). In this paper the EXAFS technique is shown to be well adapted to the determination of the species formed on alumina during impregnation.

\section{EXPERIMENTAL}

\subsection{Sample Preparation}

The preparation of the reference double layer hydroxide (DLF), hydroxides, and basic salts has been reported previously [5]. Impregnated samples were prepared by stirring during $1.5 \mathrm{~h} 5 \mathrm{~g}$ of $\mathrm{Al}_{2} \mathrm{O}_{3}$ powder in $200 \mathrm{~mL}$ of $\mathrm{Co}$ (II) or $\mathrm{Ni}$ (II) nitrate solutions containing $1 \mathrm{M}$ ammonium nitrate. The $\mathrm{pH}$ was adjusted to 7.2 and 8.1 for $\mathrm{Ni}$ (II) and Co(II) respectively by bubbling ammonia.

\subsection{XAS measurements}

EXAFS measurements at the Ni and Co K edges were performed at the LURE radiation synchrotron facility (Orsay, France) using the D44 X-ray beamline emitted by the DCI storage ring (positon energy $1.85 \mathrm{GeV}$; ring current $300 \mathrm{~mA}$ ). The spectra were recorded at $77 \mathrm{~K}$ in the transmission mode using two air filled ionization chambers. A Si(331) monochromator was used. Data analysis was performed using the University of Washington XAFS analysis package. 


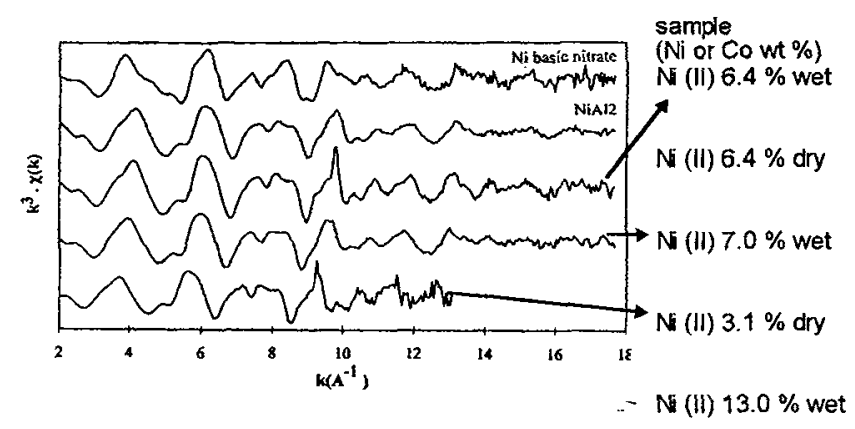

\begin{tabular}{|c|c|c|c|c|c|}
\hline $\begin{array}{c}\text { backscatterer } \\
O \\
\mathrm{~N} \\
\mathrm{~A}\end{array}$ & $\begin{array}{l}N \\
5.9 \\
4.0 \\
1.8\end{array}$ & $\begin{array}{c}R \\
(\AA) \\
2.05 \\
3.05 \\
3.05\end{array}$ & $\begin{array}{c}\left(10^{5} \mathrm{~A}\right) \\
8.1 \\
7.0 \\
7.0\end{array}$ & $\begin{array}{l}\Delta E_{n} \\
(\mathrm{eV}) \\
-1.0\end{array}$ & $\begin{array}{c}\mathrm{M}(\mathrm{UI}) \\
\mathrm{M}(\mathrm{III}) \\
2.2\end{array}$ \\
\hline $\begin{array}{l}O \\
N \\
\mathrm{Al}\end{array}$ & $\begin{array}{l}5.6 \\
3.6 \\
2.0\end{array}$ & $\begin{array}{l}2.05 \\
3.05 \\
3.05\end{array}$ & $\begin{array}{l}7.7 \\
7.3 \\
7.3\end{array}$ & -1.5 & 1.8 \\
\hline $\begin{array}{l}O \\
N \\
\mathrm{Al}\end{array}$ & $\begin{array}{l}5.2 \\
3.6 \\
1.5\end{array}$ & $\begin{array}{l}2.05 \\
3.05 \\
3.05\end{array}$ & $\begin{array}{l}5.2 \\
6.9 \\
6.9\end{array}$ & -0.5 & 2.4 \\
\hline $\begin{array}{l}O \\
N \\
A\end{array}$ & $\begin{array}{l}5.6 \\
3.6 \\
2.5\end{array}$ & $\begin{array}{l}2.05 \\
3.04 \\
3.04\end{array}$ & $\begin{array}{l}6.3 \\
5.3 \\
5.3\end{array}$ & 2.6 & 1.4 \\
\hline $\begin{array}{l}\mathrm{O} \\
\mathrm{N} \\
\mathrm{Al}\end{array}$ & $\begin{array}{l}5.5 \\
4.4 \\
1.5\end{array}$ & $\begin{array}{l}2.05 \\
3.07 \\
3.07\end{array}$ & $\begin{array}{l}7.7 \\
8.4 \\
8.4\end{array}$ & 1.0 & 2.9 \\
\hline $\begin{array}{c}O \\
N \\
\text { Al }\end{array}$ & $\begin{array}{l}5.3 \\
4.2 \\
1.6\end{array}$ & $\begin{array}{l}2.05 \\
3.06 \\
3.06\end{array}$ & $\begin{array}{l}9.4 \\
7.3 \\
7.3\end{array}$ & 2.0 & 2.6 \\
\hline $\begin{array}{l}\mathrm{O} \\
\mathrm{Co} \\
\mathrm{Al}\end{array}$ & $\begin{array}{l}5.1 \\
3.0 \\
2.2\end{array}$ & $\begin{array}{l}2.08 \\
3.09 \\
3.09\end{array}$ & $\begin{array}{l}5.5 \\
7.0 \\
7.0\end{array}$ & 4.6 & 1.4 \\
\hline $\begin{array}{l}0 \\
\text { Co } \\
\text { Al }\end{array}$ & $\begin{array}{r}5.1 \\
2.7 \\
2.3 \\
+20 \%\end{array}$ & $\begin{array}{l}2.08 \\
3.08 \\
3.08 \\
+2 \%\end{array}$ & $\begin{array}{c}5.2 \\
5.7 \\
5.7 \\
+20 \%\end{array}$ & 4.8 & 1.2 \\
\hline
\end{tabular}

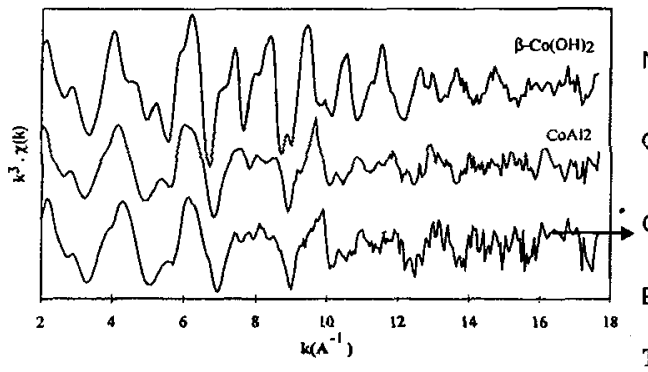

N. (II) $13.0 \%$ wet

Co (II) $2.4 \%$ wet

Co (II) $2.7 \%$ wet

Estimated precision

Table I: Structural parameters of impregnated samples as determined by

Figure 1: $k^{3}$ weighed EXAFS at the $\mathrm{Ni}$ (above) and Co EXAFS at the $\mathrm{Ni}$ and $\mathrm{Co} \mathrm{K}$ edge.

(below) $\mathrm{K}$ edges of hydroxides, basic nitrates, reference $\mathrm{DLH}$ of atomic ratio $\mathrm{M}$ (II)/AI(III) $=2$, and impregnated samples (arrows point to the corresponding sample in the table).

\section{RESULTS AND DISCUSSION}

Direct examination of the spectra in Figure 1 showed that the signal of the DLH reference compounds can be readily distinguished from that of hydroxides and basic salts, in particular in the 4-6 $\AA^{-1}$ and the 7-9 $\AA^{-1}$ ranges. This demonstrated that EXAFS is sensitive to the presence of aluminum in the precipitates. The spectra of the impregnated samples were similar to the ones of DLH, supporting the assumption that DLH was formed in these samples.

Data analysis led to absorber-backscatterer distances consistent with X-ray data, while the M(II)/Al(III) atomic ratio determined for the DLH reference compounds was in agreement with the samples compositions (not shown). Therefore detailed analysis of the EXAFS data of the impregnated samples was performed. The structural information extracted from the EXAFS data is presented in Table I. In all impregnated samples, the formation of DLH was confirmed and the amount of aluminum incorporated from the support was estimated. An important point is that these observations are unambiguous whatever the crystallinity of the structures may be.

\section{CONCLUSION}

EXAFS clearly demonstrated that even at $\mathrm{pH}$ close to neutrality, aluminum is extracted from the alumina support and incorporated in a secondary DLH phase. We suggest that three phenomena occur simultaneously at the oxide/water interface in the presence of metal ions: (1) adsorption of the originally solvated ions, (2) dissolution of alumina which is rate-limiting but may be accelerated by the metal ion adsorption, and (3) the coprecipitation of cations released from the support, $\mathrm{Al}^{3+}$, with the metal ion in solution leading to the DLH structure. Thus, alumina should not be considered systematically as inert even at $\mathrm{pH}$ values close to its isoelectric point.

\section{References}

[1] James, R. O., Healy, T. W., J. Colloid Interface Sci. 40 (1972) 42.

[2] Hering, J. G., Stumm, W., Langmuir 7 (1991) 1567.

[3] Kung H. H., Transition metal oxides: surface chemistry and catalysis. Studies in surface science and catalysis, vol. 45 (Elsevier, Ansterdam, 1989) p. 131.

[4] Espinose de la Caillerie, J.-B. d', Kermarec, M., Clause, O. J. Phys. Chem. 99 (1995) 17273-17281.

[5] Espinose de la Caillerie, J.-B. d', Kermarec, M., Clause, O. J. Am. Chem. Soc. 117 (1995) 11471-11481. 